\title{
Bryan McCan. Hard Times in the Marvelous City. From Dictatorship to Democracy in the Favelas of Rio de Janeiro. Duke University Press, 2014.
}

Marie Kolling 1

Hard times in the Marvelous City examines the favela activism movement in Rio de Janeiro, and their quest for equal rights and integration into the formal city from the late nineteen seventies under the military dictatorship. This struggle continues until today and this book puts that struggle into an historical perspective that reminds us of both how much and how little has been achieved. It tells the story of how Rio's favelas have developed, consolidated and diversified since the seventies until today and reveals their fight against forced removal and demands for land tenure and municipal reforms, some of which were achieved and reached as far as the federal constitution. By examining the formation of favela associations, the collective activist favela movements, and their leaders' entry into city politics, the book outlines the conditions for community politics. It also shows how they change with the establishment of democracy and with the transitions of municipal and state politicians.

Paradoxically, the establishment of democracy and political reforms did not in itself improve the conditions for the community leaders and favela activists as expected. When democracy was reinstated in 1985, Brazil, as well and many other Latin American nations, experienced a devastating economic crisis, and in 1988 the municipality of Rio was eventually declared bankrupt due to a combination of misfortunes. Concomitantly, huge numbers of migrants arrive in the city and the favelas expand exponentially in this period, while the city also experiences a dramatic increase in organized drug trafficking,

\footnotetext{
${ }^{1} \mathrm{PhD}$ Fellow, Department of Anthropology, University of Copenhagen.
}

Brasiliana - Journal for Brazilian Studies. Vol. 3, n.1 (July. 2014). ISSN 2245-4373. 
crime and violence.

The formation of criminal factions takes its toll on many of Rio's favelas in the mid-eighties, protecting their turf through violence and patronage. Favela resident associations are soon co-opted by the criminal leaders and this takeover becomes increasingly evident and eventually explicit in the nineties. It is left unchallenged, however, as the drug traffickers impose a violent regime and do not tolerate critique. They present themselves as social bandits defending neglected communities. They provide the residents safety (from rival gangs and police violence), which the police fail to do, as well as material benefits and social cohesion, which the politicians fail to provide. This representation of the drug traffickers is criticized by the author of the book, for whom the media also played a part in. For McCan, this representation of the drug dealers was left unchallenged and at times even reinforced by community leaders, favela activists, residents, NGO workers (NGOs spread rapidly in Rios favelas through the nineties), politicians and policy makers. Only some scholars challenged this image, which has been decisive in the relations between the favelas and the rest of the city. The favelas were perceived as the source of urban crime and violence, and with criminals 'representing' them only worsened the immense discrimination the residents still suffer today and the myth of the absence of the state in the favelas. McCan shows why the favelas have come to be perceived as irrevocably different and autonomous entities from the formal city, while most of them feel in fact were very much connected. These connections are largely based on clientelism and the people in power seeking opportune alliances with the favela residents stuck in the middle, being valuable voters for the politicians and loyal clients to those willing to make immediate improvements to their living conditions. With the drug traffickers seemingly in power, as well as militias whose emergence is also elaborated in the book, it explains how funding that is

Brasiliana - Journal for Brazilian Studies. Vol. 3, n.1 (July. 2014). ISSN 2245-4373. 
channeled into the favelas ends up serving their ends and power positions, which reinforces the gap between the favelas and the city.

Throughout the book, attention is paid to the political visions and strategies created for the favelas and efforts of bridging the gap between the favelas and the formal city especially during Leonel Brizola's recurring periods of governance. What is striking about the examination of the political connections between the favelas and the city over the course of three decades is that it is not simply a lack of political will to close this gap that has sustained it. At times, it has also been a lack of unity among those representing the favelas, the serving of their own interests, and not least the dominance of criminal networks. This, for instance, results in the failure to provide property titles for favela residents. Essentially, however, the connection centers on votes and party politics. This overview is an important contribution to the bourgeoning literature on Rio's favelas and their place in the city.

The book is eloquently written, and McCan weaves in Brazilian expressions with concise explanations, which make the book resemble an anthropological monograph. It is based upon in-depth research using a mixed-method approach and it is clearly evident that McCan has spent a long period of time with people in Rio's favelas, which, also gives the book a monographic feel. Throughout the book, it is, however, often not made explicit which sources of data McCan draws upon regarding the different sites and events (whether his own interviews, a policy report, Brazilian newspapers or PhD dissertations). Nor is it always clear when he is drawing his own conclusions or presenting those of others. Everything is presented with the same factual manner, which in my opinion is the weakness of the book. As the book tells the story of the development of Rios favelas collectively, while providing insights into specific pivotal events in different favelas, I also found these jumps from one site to another, at times

Brasiliana - Journal for Brazilian Studies. Vol. 3, n.1 (July. 2014). ISSN 2245-4373. 
both in time and space, a little confusing.

The domination of the strong criminal networks in Rios favelas puts security politics at the forefront of the state-favela nexus. Here, Hard Times provides a valuable insight into the changing security policies, police practices and their outcomes, which is highly topical with Rio hosting the World Cup in June and July 2014 and the Summer Olympics in 2016. These events have been motivation for the 'Favela Pacification Strategy' that began implementation five and half years ago. It was interesting to learn that many of the elements in the pacification strategy (of occupying favelas using military strategies, and at times military personnel, and set up community police station with young officers trained in human rights who hopefully will treat the residents with respect and less rights violations and abuse) are not new ideas. This time around the strategy is more comprehensive and has increased political support on municipal, state and federal levels. However, reading about the failed attempts in the past and the difficulties in changing the attitude among the police towards favela residents, which worsens with the criminal drug traffickers' alleged representation of the communities, puts into perspective how a profound change is needed for this security strategy to work. After decades of hostility and distrust between the police and the residents, which the criminal leaders and political hardliners have had their share in exacerbating, it will require immense work to create real change.

Likewise, as an anthropologist studying the current slum upgrading policies and practices in Northeast Brazil it was highly interesting reading to discover that many current initiatives and issues are in fact not new. For instance, the initiative to provide residents of informal housing the right to adverse possession rather than actual land titling is not new, nor is the problem of initiating such programs, and a lack of success with their implementation. Also, the problem for favela association leaders mobilizing

Brasiliana - Journal for Brazilian Studies. Vol. 3, n.1 (July. 2014). ISSN 2245-4373. 
residents in the struggle against removal was already an issue in the seventies, as was urban upgrading causing gentrification. Another struggle was trying to organize mutirão, volunteer collective labour in the community, which urban planners until this day attempt to implement largely to no avail (apart from a few success stories e.g. in São Paulo). That was troublesome reading. Nonetheless, the book is a must read for students and scholars who wish to gain an insightful historical description of Rio's favelas and their place in the city as well as a contextualization of current issues regarding these relations. 